Esta publicación cientifica en formato digital es continuidad de la revista impresa ISSN-Versión Impresa 0798-1406 / ISSN-Versión on line 2542-3185Depósito legal pp
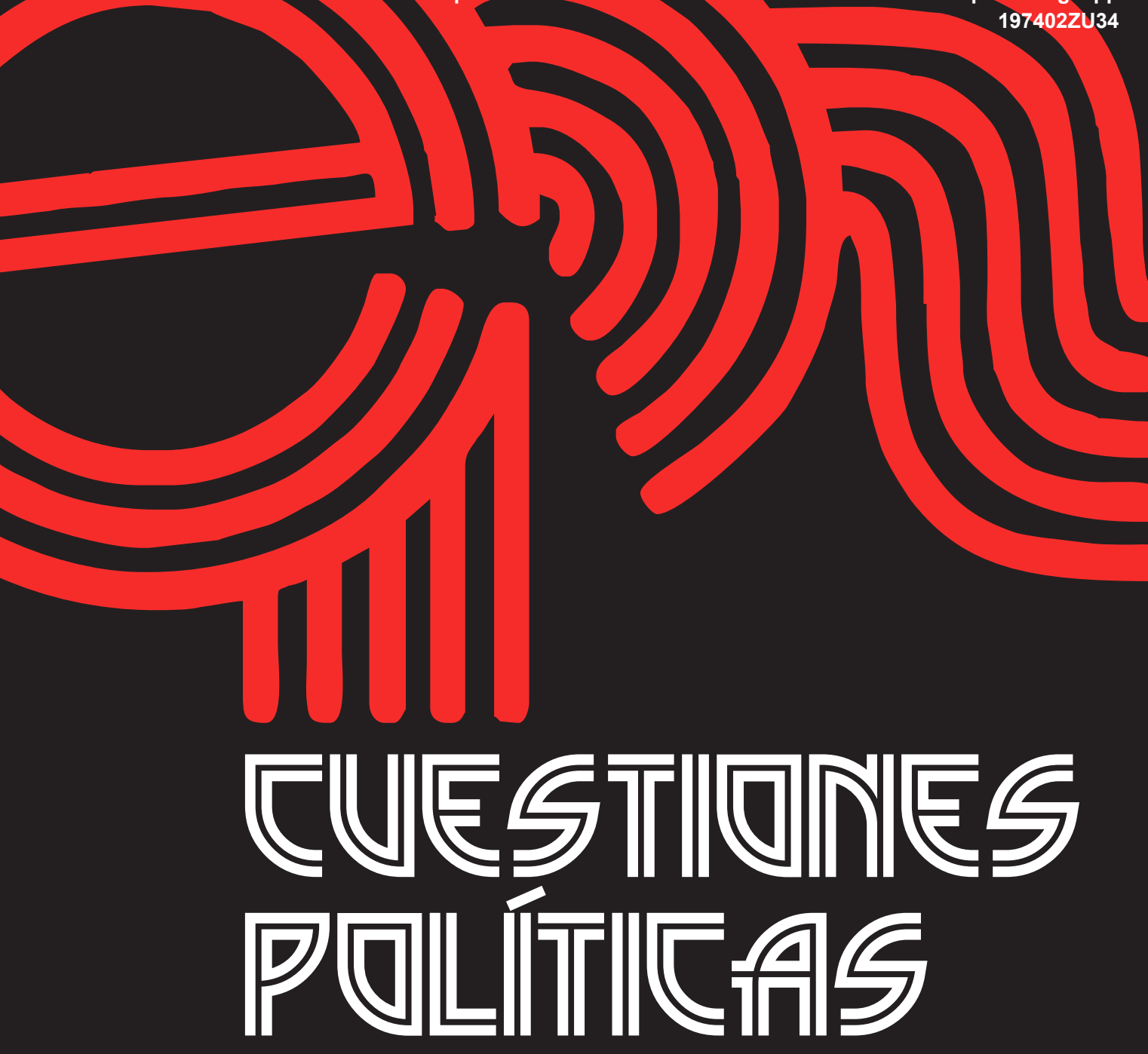

Instituto de Estudios Políticos y Derecho Público "Dr. Humberto J. La Roche" de la Facultad de Ciencias Jurídicas y Políticas de la Universidad del Zulia Maracaibo, Venezuela
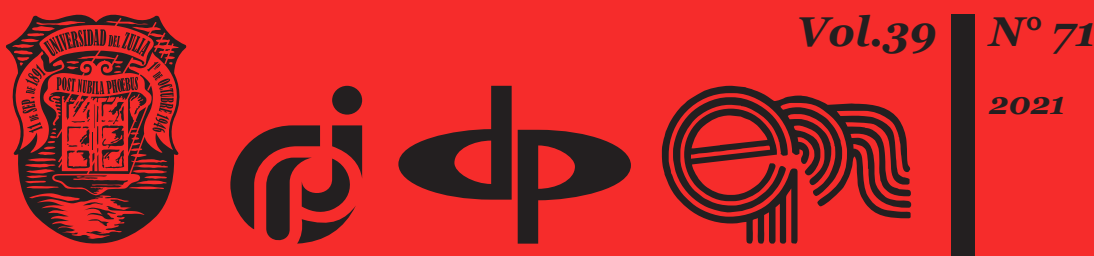


\title{
Preventive diplomacy as a tool for conflict solutions in Eastern Europe
}

\author{
DOI: https://doi.org/10.46398/cuestpol.3971.27
}

\author{
Iryna Habro * \\ Mykhailo Fedorenko ** \\ Liudmyla Vovchuk *** \\ Tatiana Zholonko ****
}

\begin{abstract}
The modern world community is concerned about the search for humane, non-forceful methods for solving hybrid conflicts that characterize the system of international relations of the 21st century. That is why the concept of preventive diplomacy has become popular and in demand. The conflict in the East of Ukraine has shown that this concept has some flaws in terms of its implementation in practice. Using the historical method, the key means of implementing preventive diplomacy are revealed. The article analyzes examples of the use of preventive diplomacy methods for solving conflicts in Europe by the Organization for Security and Cooperation in Europe. The authors used the method of comparative analysis to compare examples of implementation of the principles of preventive diplomacy by different international players. Attention is drawn to the fact that excessive caution of the OSCE and unwillingness to call Russia a participant in the conflict and even more, so an aggressor country led to skepticism about the
\end{abstract} organization itself in Ukraine.

Keywords: Foreign policy in Europe; preventive diplomacy; confidencebuilding measures; clarification of the facts; preventive deployment and demilitarization of the territory.

* $\quad$ Ph.D. in Political Science, Department of International relations and foreign policy Petro Mohyla Black Sea National University, Ukraine. ORCID ID: https://orcid.org/oooo-ooo1-8215-7615

** Ph.D. in History, Department of Social and humanitarian disciplines Admiral Makarov National University of Shipbuilding, Ukraine. ORCID ID: https://orcid.org/oooo-0003-1713-6492

*** Ph.D. in History, Department of International relations and foreign policy Petro Mohyla Black Sea National University, Ukraine. ORCID ID: https://orcid.org/oooo-0002-7201-1388

**** Ph.D. in Political Science, Department of Social Sciences and Humanities Robert Elworthy Institute of Economics and Technology, Ukraine. ORCID ID: https://orcid.org/oooo-0002-3541-679X 


\section{La diplomacia preventiva como herramienta para la solución de conflictos en Europa del Este}

\section{Resumen}

La comunidad mundial moderna está preocupada por la búsqueda de métodos humanos y no contundentes para resolver los conflictos híbridos que caracterizan el sistema de relaciones internacionales del siglo XXI. Es por eso por lo que el concepto de diplomacia preventiva se ha vuelto popular y solicitado. El conflicto en el este de Ucrania ha demostrado que este concepto tiene algunas fallas en términos de su implementación en la práctica. Usando el método histórico, se revelan los medios clave para implementar la diplomacia preventiva. El artículo analiza ejemplos del uso de métodos de diplomacia preventiva para resolver conflictos en Europa por parte de la Organización para la Seguridad y la Cooperación (OSCE) en Europa. Los autores utilizaron el método de análisis comparativo para comparar ejemplos de implementación de los principios de la diplomacia preventiva por diferentes actores internacionales. Se concluye que llama la atención el hecho de que la excesiva cautela de la OSCE y la falta de voluntad de llamar a Rusia un participante en el conflicto y más aún un país agresor llevan al escepticismo sobre la propia organización en Ucrania.

Palabras clave: Política exterior en Europa; diplomacia preventiva; medidas de fomento de la confianza; clarificación de los hechos; despliegue preventivo y desmilitarización del territorio.

\section{Introduction}

The search for ways to effectively ensure the peaceful development of any state, the analysis of the necessary prevention means that are flexible and adequate to modern types of threats and the timely elimination of conflict situations is one of the most important tasks of modern diplomacy. The sharp increase in the number and frequency of local conflicts in almost all parts of the world after the end of "the cold war" and the disappearance of the bipolar world have made it critical to find new ways and means for regulation and solving conflicts. Among these ideas, the concept of preventive diplomacy, because of its almost peaceful nature, is the most attractive.

The modern world community is concerned about the search for humane, non-forceful methods for solving hybrid conflicts that characterize the system of international relations of the 21st century. That is why the concept of preventive diplomacy has become popular and in demand. The 
conflict in the East of Ukraine has shown that this concept has some flaws in terms of its implementation in practice. After all, international structures designed to implement the ideas of preventive diplomacy include countries that are latent participants in conflicts, actual initiators. For this reason, preventive diplomacy is not always effective and does not justify the hopes placed on it.

The purpose of the study is the peculiarity of preventive diplomacy as means of conflict prevention, as well as preventive activities of the OSCE to prevent and regulate conflicts in Europe.

The problem of preventive diplomacy is popular in the works of researchers. For example, the work of the Ukrainian researcher I. Nazarovsky (Nazarovska, 2012) analyzed the range of the main subjects of preventive diplomacy and highlighted their main advantages and disadvantages, peculiarities of the involvement in the activities for preventing armed conflicts. In the works of I. Goncharenko (Goncharenko, 2006), the peculiarities of interaction between the UN and the OSCE as for prevention and non-forceful conflict solution in the post-Soviet space are investigated. Yu. Pashchuk (Pashchuk, 2002) analyzes the practice of using preventive diplomacy on the example of Yugoslavia in 1991-1995, and T. Fichora (Fichora, 2007) - on the example of the Transdniestrian conflict. However, there is no objective and impartial analysis of the use of preventive diplomacy methods in the East of Ukraine.

\section{Methodology of the study}

In the analysis of the concept of preventive diplomacy and its practical application, the author was guided by the method of historicism, which allowed to place the problem in a changing historical context, to explain the reasons for its emergence, its evolution, use by individual subjects and examples of implementation. The historical approach has made it possible to explain the causes of successes and political failures in the practical application of preventive diplomacy in a particular setting. The benchmarking method has been widely used in comparing examples of implementation of preventive diplomacy principles by various international players.

\section{Results and Discussion}

As is known, the concept of preventive diplomacy was first proposed by the UN Secretary General D. Hamerscheld. It was he who provided the first definition of preventive diplomacy, under which he understood 
the actions aimed at preventing the transfer of local conflicts to the global confrontation of two military-political alliances. However, this term came into the world practice and scientific use after the report of the UN Secretary General Boutros Boutros-Ghali, which he spoke at the 47th session of the UN General Assembly on July 17, 1992, with.

Preventive diplomacy is the official diplomatic activity of international organizations, states, their governments, aimed at preventing conflicts at the beginning of their escalation, stopping their growth, creating conditions for peace. It includes political, economic, military, and other types of activities for restoring trust between hostilities and for the earlier conflict warning.

For the success of preventive diplomacy, the combinations, and the simultaneous presence of a number of factors, both objective and subjective, are necessary. In this regard, many analysts agree that the lack of information adequate to the crisis situation is not always the cause of these failures. On the contrary, sometimes there is more than enough disturbing information, but other reasons of a more prosaic nature, such as, for example, the overload of the staff of the UN Secretariat with current conflicts or the availability of relevant state services with similar crisis situations, do not allow to pay sufficient attention to latent conflicts. As a result, sometimes due to negligence, sometimes due to the uncertainty of the level of accuracy of the incoming earlier warning signals, and sometimes because of uncertainty about the correctness of the actions taken, the elimination of latent cases does not occur.

Moreover, many people responsible for preventive actions wait until the conflict reaches the crisis phase, when they can confidently prove their actions and receive political dividends. So, one of the main subjective factors in preventive diplomacy, the so-called political will, sometimes turns out to be decisive, whereas if preventive attempts fail, inaction can always be justified by various excuses (Rakhmatullaev, 2007).

The system of subjects of preventive diplomacy consists of the government of states, international organizations (UN, OSCE, ASEAN, etc.) and non-governmental organizations. Each of these three elements of the system plays an important role in the caution, prevention, and solution of armed conflicts. For example, governments initiate military and political actions that demonstrate the credibility of a solution for a conflict; international organizations initiate coherence of international efforts, and non-governmental organizations quickly and effectively react to the challenge. Each element must be leading at a certain time and in a certain sphere and each of them has the right to count on the support and understanding of other subjects in prevention of armed conflicts. 
The achievements of these international structures in the field of conflict prevention have not always been further developed for their implementation due to the lack of political will, the policy of double standards, or ignoring the specific circumstances of particular situations. In a number of crises, the initiatives of the UN, the OSCE and other subjects of preventive diplomacy on the invention of the formula for a political regulation did not result in fundamental, qualitative changes.

\subsection{OSCE preventive diplomacy in the post-Soviet space}

The OSCE is one of the key subjects of preventive diplomacy. This organization has 57 member-states around the world, covering three continents - North America, Europe, and Asia.

A comparative analysis of institutions implementing strategies of preventive diplomacy, at the disposal of the OSCE, allows us to distinguish two key institutions - a) long-term missions; and b) the OSCE High Commissioner for National Minorities (HCNM). The long-term CSCE missions arose under the pressure of circumstances and the emergence of the need to prevent and solve the conflicts in the area of responsibility of the Organization (Rakhmatullaev, 2008).

OSCE actions taken in Lithuania have become the best example of an orderly transition from the Soviet republic to a sovereign state with regard to relations with Russia. Although a similar process took place in Estonia and Latvia, it was not so successful, however, there was some progress as well. On the one hand, the specifics of the Baltic countries, their Western political culture, historical experience, Baltic geopolitics contributed to this process. On the other hand, the OSCE's efforts to regulate relations between Russia and the Baltic states took place in fairly favorable conditions, primarily because the parties wanted solving of existing conflicts.

The center of the "Baltic question" was the presence of the Russian military on the territory of three countries. The OSCE mission, starting its work in 1992, provided a solution to the acute problems of the region: the withdrawal of troops from the territory of Lithuania, Latvia and Estonia; advice on regulations of issues of citizenship and language; guaranteeing the rights of military retirees; cooperation in the negotiations on the dismantling of the radar in Skrunda; establishing a dialogue with Western countries.

The specifics and focus of the actions of the OSCE High Commissioner on National Minorities in Latvia and Estonia helped to prevent the crisis development of events related to the restriction of the rights of the Russianspeaking minority there. 
Also worth mentioning is the practice of applying preventive diplomacy in the Moldavian-Transdniestria conflict. The most important instrument used by the OSCE was the sending of a special mission to the Republic of Moldova in response to the appeal of the Moldavian government.

The main task of the Mission was to promote the achievement of a final political settlement of the conflict in all its aspects, based on the independence and sovereignty of the Republic of Moldova, within the existing borders and restoring the territorial integrity of the state with granting special status to Transdniestria. The Mission's mandate covered several points, the main of which was to provide favorable conditions for the dialogue between the parties with the aim to solve the problem politically, as well as to establish contacts with all parties of the conflict, local administrations, local people, monitoring the situation, providing recommendations and expert assessments, monitoring compliance of international obligations to ensure human and minority rights, the return of refugees, etc. (Fichora, 2007).

In December 1999, according to the $19^{\text {th }}$ Paragraph of the Declaration of the Istanbul Summit, the Mission's mandate was expanded with the aim to ensure transparency in the process of removing and destroying of Russian ammunition and weapons, to coordinate financial and technical assistance that was provided to facilitate the implementation of their withdrawal and destruction. The OSCE Mission (then it was CSCE) in Moldova began its activities on April 25, 1993, in Chisinau (Melnyk, 2013). The Memorandum of Mutual Understanding with the Government of the Republic of Moldova was signed on May 7, 1993 and amended on March 28, 1996. The mutual understanding of the OSCE activities in the Transdniestria region came into force on August 25, 1993, as a result of an exchange of letters between the Head of the Mission and the president of the so-called Transdniestrian Moldavian Republic (hereinafter - the TMR). The mission opened its office in Tiraspol on February 13, 1995. In September 1993, the cooperation of the Joint Control Commission with the OSCE Mission in the Republic of Moldova was established. And in November 1993, the Head of the OSCE Mission in Moscow, T. Williams, sent Report No. 13 to the head of the organization. This document described the Mission's viewpoints on how to solve the conflict and a possible basis for negotiations between the two parties (Melnyk, 2013).

It should be noted that since 1993, the OSCE Mission has been considered the main mediator in this conflict. It was the OSCE that constantly promoted peace negotiations between Moldova and the TMR. The negotiations in the " $5+2$ " format was particularly active, in which Moldova and the TMR as parties of the conflict, Russia, Ukraine and the OSCE as mediators, as well as the US and the EU as observers, take part. The negotiations were interrupted in 2006, then they were restored several times in 2011 and 
2016. In addition to a direct political regulation, the OSCE focuses on confidence building measures and interpersonal contacts through informal negotiations during meetings of experts on humanitarian and social issues (Zvezdova, 2017).

For many years, the Mission has been actively involved in discussions dedicated to ensuring military transparency and restoring confidence between the parties of the conflict. Only during the first half of 2004, the Mission's experts proposed 14 draft agreements on confidence and security building measures. The proposals drew attention to the possible reduction of the armed forces and armaments; they also included the intensification of contacts, monitoring of weapons production capacities, joint exercises for peacekeeping operations, joint inspection exercises and so on.

It should be noted that the OSCE's activities in the regulation of the Transdniestrian conflict have an ambiguous assessment. On the one hand, the involvement of this organization in the regulation process has had a positive significance, since it allowed to internationalize the negotiation process and attract the attention of the international community, because with the assistance and support of the OSCE the format of the negotiations was expanded. In addition, the presence of the OSCE Mission restrained the hostile actions of the parties in conflict situations since awareness of the fact of oversight from the side of the international community was important.

However, sharp criticism exists towards this organization, and not without reasons. The criticism concerns the ineffectiveness of the peacekeeping efforts and the monitoring mission of the OSCE. There are no effective tools and levers in the OSCE that could force countries to fulfill their commitments. And it is vividly seen in the failure of the OSCE to achieve the implementation of the decisions of the Istanbul Summit on the export of weapons and ammunition of the Russian $14^{\text {th }}$ Army from the territory of Transdniestria. The procedure for making decisions and coordinating activities continues so long that sometimes a moment for the effective implementation of this decision is lost (Fichora, 2007).

In addition, the activities of the OSCE Mission in Moldova are extremely negatively perceived on the left bank of the Dniester. Although the OSCE office operates in Transdniestria, this organization is not trusted there, it is criticized for formalism, prejudice, and bias. In the opinion of Transdniestria's, the OSCE monitoring is one of the methods of collecting military strategic information. The OSCE is accused of becoming a tool of pressure, pursuing a policy of double standards, and protecting the interests of the Western world, regardless of the objective reality existing in the conflict zone. Of course, this is the result of propaganda, and first of all, Russian one. 


\subsection{OSCE and preventive diplomacy in solving the conflict in the East of Ukraine}

Ukraine has been a member of the OSCE since January 30, 1992, when the first president of independent Ukraine, Leonid Kravchuk, signed the Helsinki Final Act. For a long time, Ukraine has been actively involved in regulation of conflicts under the auspices of the OSCE. However, after the start of the Russian aggression, Ukraine has turned from a donor to a recipient of international security and is now forced to seek external support in order to restore peace.

In the practice of international peacekeeping, the responses to the challenges that Ukraine faces now have long been processed, and even a simple linear projection of the state of conflict on the forms of peacekeeping assistance allows to avoid false expectations and answer the question of what kind of peacekeeping assistance Ukraine needs.

As noted by the Ukrainian expert V. Filipchuk, already during the Maidan - in February 2014 - Ukraine should have called for the preventive deployment of an international peacekeeping contingent. Preventive deployment is one of the most effective mechanisms of international influence to prevent the escalation of violence, allowing in a number of cases to stop conflicts before the start of their active phase. But the restraint of international players and the short-sightedness of the Ukrainian political leadership led to the fact that this issue was not even considered at the international level. Only a year after several military defeats, the loss of territories, the deaths of thousands of Ukrainians, the conversion of millions of citizens into refugees, and finally the signing of Minsk-2, the Ukrainian leadership turned at last to the international community with a request to introduce a "peacekeeping" contingent (Filipchuk, 2016).

The annexation of Crimea put the world community before the fact that one member state of the UN and the OSCE violates the territorial integrity of the other state through direct use of military force. The Russian special services removed the Special Representative of the UN Secretary General in Ukraine from the territory of Crimea during the annexation, the peninsula was removed from international monitoring altogether. To facilitate the regulation of the conflict on the territory of the Donetsk and Luhansk regions, the OSCE has been determined as the main format of international involvement. But the mandate and activities of the OSCE Special Monitoring Mission in Ukraine, the OSCE Observer Mission on the Russian-Ukrainian border, as well as the OSCE's activities to facilitate the operation of the tripartite contact group (the Minsk process) did not help to stabilize the situation in the Donbass, but also failed to prevent an escalation of the armed conflict (Filipchuk, 2016). 
Standard mechanisms that the OSCE uses to solve conflicts under the conditions of conflict in the East of Ukraine do not work. The Minsk process and the agreements that are accepted during its work are not effective. These agreements are violated almost immediately after their approval.

In Ukraine, a special monitoring mission of the OSCE is now operating, but its capabilities are limited - it has neither the ability to coerce, nor the ability to protect itself. Moreover, the mission's right to free movement and monitoring in the conflict zone is systematically violated from the side of the militants, and the OSCE representatives themselves often become objects of aggression by military formations in the East of Ukraine. Ukraine has repeatedly expressed a request to strengthen the existing mission with an additional mission under a military mandate or a police component.

Excessive caution of the OSCE and unwillingness to call Russia a participant in the conflict, and even more so an aggressor country, lead to skepticism towards the organization itself in Ukraine. The situation is similar to how the OSCE is perceived in Moldova and Transdniestria. In addition, in the mission of the OSCE observers there are representatives of Russia, which also does not contribute to the increase of the credibility to the OSCE among Ukrainians. When one state is at the same time a party of the conflict and a mediator, this is nonsense. One can only imagine how this situation affects mission reports, their content and language.

The Russian Federation has many levers of influence on the functioning of the OSCE. Consensus must be not only in political, but also in administrative decisions. In particular, in decisions to send a mission or extend its mandate. Many of those who came to the East of Ukraine, had experience in other missions. For example, in Bosnia. There, they promoted dialogue between Bosnian Muslims, Serbs, and Croats. They put in their memory that the mission should facilitate dialogue. They intended to act in Ukraine in such a way as well. At the beginning, it was believed that the conflict in Ukraine was a civil conflict, where there are two sides - the majority of the population of the state and residents of the East, in particular of the Donbass. Only later they realized that this was not an internal conflict. Therefore, in this case, the mission's mandate was inadequate to the situation.

The definition of the Ukrainian crisis as an internal conflict between Ukraine and ORDLO (separate districts of the Donetsk and Luhansk regions) excludes the deployment of an international peacekeeping operation, and regulation of the conflict due to the implementation of the Minsk agreements is an obligation of Ukraine, which was approved by the UN Security Council resolution (Zartman, 1996). The Minsk agreements are only a mechanism for transforming the war in the East of Ukraine into a conflict of low intensity, but it continues in the acute stage. The use of preventive diplomacy will only contribute to the localization of the conflict and its non-proliferation to other regions of Ukraine and neighboring 
countries, which is not expedient in this situation. Therefore, the only effective form in this case would be assistance to peace using the whole arsenal of efforts provided by Art. 33 of the UN Charter (negotiations, examination, mediation, arbitration, appeal to regional organizations), with the following use of peace-building form and peace enforcement of the Russian Federation, however, with the official qualification of Russia as the aggressor country, and then the removal of the Russian Federation when considering the issue of Ukraine in the UN Security Council (Panchenko, 2016).

It should be noted that some members of the OSCE realized that Russia is a party of the conflict, but this happened only after the tragedy with the Boeing 777 in July 2014. But then it was too late to remove Russia from the mission to the East of Ukraine. This could, but only theoretically, be done at the very beginning - in the spring of 2014. But then, and now this requires political will in the countries of the West. Western politicians, even those who personally would like to increase the pressure on Russia in the OSCE, should take into account the opinion of Western society. And their anti-war sentiments are dominant.

It is also necessary to say that the OSCE insists on the principles of tolerant relationships between the parties of the conflict in Ukraine. Back in 2014 in Minsk, representatives of the organization offered to adopt the relevant documents on amnesty at the level of national legislation in Ukraine.

In the conditions of the conflict, an amnesty is understood as a deliverance from criminal prosecution and, possibly, from civil liability, limited by the conduct that took place during a specified period and/or related to a military conflict.

The world experience is rich in the application of amnesty in different countries and with a different purpose. Under some conditions, amnesties for "ordinary" criminal offenses may have a humanitarian purpose, for example, to allow terminally ill persons to return home or to ease the harsh conditions in overcrowded prisons.

At the insistence of the OSCE and the world community, Ukraine adopted a relevant law - the Law of Ukraine "On the Prevention of Prosecution and Punishment of the participants of the events on the territory of the Donetsk and Luhansk regions" dated September 16, 2014. This document was approved to facilitate the peaceful regulation of the situation in the East of Ukraine and was adopted in compliance with the Minsk agreements, where an amnesty was introduced for all parties of the conflict, without the possibility of granting a conditional amnesty and establishing responsibility for war crimes (Panchenko, 2016). 
Accordingly, the persons referred to in the first part of Article 1 of the document

Are exempt from criminal responsibility, provided that, after a month since the entry into force of this Law, they fired or do not hold hostages, voluntarily surrendered to state bodies or do not keep firearms, ammunition, explosives, explosive devices, military equipment, do not occupy buildings, premises of state bodies and local self-government bodies and do not take part in blocking the work of state bodies authorities, local authorities, enterprises, institutions, organizations in the Donetsk and Luhansk regions, about which they filed a relevant application to the pre-trial investigation authority conducting the criminal proceedings (Abugu, 2000: 29).

Also, in this document it is not specified what time frame for the commission of crimes is in question.

In addition, the consequence of an amnesty for such persons is the closure of criminal proceedings. Article 4 establishes:

Exemption from administrative responsibility of persons who committed from February 22, 2014, to the date of entry into force of this Law inclusive in the territory of the Donetsk and Luhansk regions where the antiterrorist operation was carried out, acts containing signs of administrative offenses envisaged in the Code of Ukraine on administrative offenses.

Even though the list of administrative offenses for the commission of which the exemption from administrative responsibility is provided, isn't specified, the exemption from any administrative offense is presumed.

Ukraine should be very careful about the issue of amnesty in the aspect of the armed conflict in the Donbass. If Ukraine should introduce amnesty, it is only conditional, because the provision of a broad, unconditional amnesty can create social tension in the society. The introduction of conditions for granting amnesty makes it difficult to solve the conflict, at the same time increases the legitimacy of the amnesty, contributes to reconciliation of the population.

Several conditions are crucial for performance. First of all, this is disarmament and demobilization, which is the key to further solution and stabilization of the situation. Refusal of violence and release of prisoners of war and hostages are obligatory requirements for granting amnesty. No less important is the prediction of the conditions for the future behavior of the persons who received the amnesty. But in any case, to implement and highlight the main ideas and requirements for the granting and preservation of amnesty, a law is needed that would regulate in detail the conditions under which amnesty is granted. Monitoring the fulfillment of such conditions would make it impossible for abuse on the part of persons who apply for an amnesty, or for officials who make decisions about its provision, as well, would perform a preventive function, establishing 
conditions for further behavior of persons for preserving the amnesty, and would provide a measure of responsibility in case of violation of these conditions.

\section{Conclusion}

Preventive diplomacy as a tool for conflict prevention was first used only in specific cases, and over time, preventive activity started to have a character of the daily work of subjects of preventive diplomacy. The use of preventive technologies has had positive results on the European continent: Macedonia, Albania, Latvia, and Estonia, etc. At the same time, there are unsuccessful attempts to prevent crises in Croatia, Moldova, Bosnia, and Serbia.

All successful attempts to apply preventive diplomacy methods were such because of the willingness of the governments of these countries to work, the countries were able to control the special services and the armed forces. The failures of the use of preventive diplomacy are primarily due to the unwillingness of politicians to solve conflicts and the long-term ignoring by the world community of those conflicts that were inevitable.

The Transdniestria conflict and the conflict in the East of Ukraine are examples of how preventive diplomacy achieved partial success. Because these conflicts do not have a large scale and numerous victims. In this result of preventive diplomacy methods, the OSCE is often blamed, which does not conflict with the Russian Federation, denies that Russia is a party of these conflicts and does not fully perform the functions assigned to this organization.

\section{Bibliographic References}

ABUGU, Anthony Ifeanichuk. 2000. "The role of preventive diplomacy in contemporary international law" In: UDN Journal of Law. Series: Law. No. 2, pp. 103-107.

FICHORA, Tatiana. 2007. "OSCE Participation in the Transnistrian Conflict Resolution" In: Foreign Policy and Diplomacy: A Historical and Modern Dimension. No. 13, pp. 99-105.

FILIPCHUK, Vasyl. 2016. International peacekeeping and war in eastern Ukraine: are there points of contact? Preventive diplomacy, peacekeeping, peace support and peacebuilding in the settlement of the «Ukrainian conflict». Kyiv, Ukraine. 
Iryna Habro, Mykhailo Fedorenko, Liudmyla Vovchuk y Tatiana Zholonko

504

Preventive diplomacy as a tool for conflict solutions in Eastern Europe

GONCHARENKO, Igor. 2006. “"Early warning” of the UN and OSCE in the post-Soviet space" In: Scientific Bulletin of the Diplomatic Academy of Ukraine. No. 12, pp. 401-431.

MELNYK, Svitlana. 2013. “Preventive Diplomacy: Myth or Reality?” In: Foreign Affairs. No. 3, pp. 46-49.

NAZAROVSKAYA, Iryna. 2012. "The main subjects of preventive diplomacy" In: Actual problems of international relations. Vol. 1, No. 108, pp. 114121.

PANCHENKO, Ludmila. 2016. The newest forms of international legal regulation of peacekeeping activity. Kiev, Ukraine.

PASHCHUK, Yuriy. 2002. "The Conflict in Yugoslavia (1991-1995): Preventive diplomacy and UN military intervention" In: Bulletin of Lviv Polytechnic National University. No. 451: State and Army, pp. 102-108.

RAKHMATULLAEV, Erkin. 2007. "The emergence and evolution of the concept of preventive diplomacy" In: Bulletin of the Saratov State Social and Economic University. Vol. 1, No. 15, pp. 127-134.

RAKHMATULLAEV, Erkin. 2008. Preventive diplomacy: theory, practice and its prospects in Central Asia. Diplomatic Academy of the Ministry of Foreign Affairs of the Russian Federation. Moscow, Russia.

ZARTMAN, William. 1996. "Conflict Prevention and Mitigation: Goals that should be shared by all countries" In: JUSIA Electronic Journals. Vol. 1, No. 19. Available online. In: http://usmfo.state.gov/ioumals/itps/1296/ iipr/pi 19zart.htm. Consultation date: 08/02/2021.

ZVEZDOVA, Olesia. 2017. The official position of international organizations on the status of Transnistria. In: Collection of Proceedings of the International Scientific and Practical Conference «Olbian Forum 2017» (Mykolaiv-Kobleve, June 2017). Black Sea National University. Petra Mogili. View of the ChNU them. Petra Mogili. Mykolaiv, Ukraine. 
Vol. 39 N $^{\circ} 71$

Esta revista fue editada en formato digital y publicada en diciembre de 2021, por el Fondo Editorial Serbiluz, Universidad del Zulia. Maracaibo-Venezuela 